Shou, W., Wu, P., and Wang, J. (2019). “A Survey of Simulation Modelling Techniques in Lean Construction Research." In: Proc. 27 $7^{\text {th }}$ Annual Conference of the International. Group for Lean Construction (IGLC), Pasquire C. and Hamzeh F.R. (ed.), Dublin, Ireland, pp. 1093-1104. DOI: https://doi.org/10.24928/2019/0142. Available at: 〈www.iglc.net>.

\title{
A SURVEY OF SIMULATION MODELLING TECHNIQUES IN LEAN CONSTRUCTION RESEARCH
}

\author{
Wenchi Shou ${ }^{1}$, Peng Wu' ${ }^{2}$, and Jun Wang ${ }^{3}$
}

\begin{abstract}
Over the past two decades, discrete event simulation (DES) has been increasingly employed in lean construction research as a response to the requirement of evaluating the impact of the implementation of various lean initiatives. A systematic review of DES application in lean construction research is necessary to examine how DES has been implemented in lean research. This review was conducted by reviewing 49 DES papers published in peer-reviewed journals and IGLC conference between 1997 and 2018, which aims to identify the state of the art development in this specific research area and propose future research directions. The papers are analysed in terms of publications, DES techniques, value of DES, and topic coverage. 13 types of DES techniques, 6 value of DES in lean construction research, and 8 research topics are identified and summarised. The findings of this study are expected to provide useful suggestions for the future research opportunities of DES in lean construction research.
\end{abstract}

\section{KEYWORDS}

Lean construction, discrete event simulation, review.

\section{INTRODUCTION}

Discrete event simulation (DES) has attracted increasing interest in lean construction research, which has been applied to evaluate and validate the effectiveness and efficiency of the proposed lean model as a response to the requirement of evaluating the applicability of lean principles and measuring their impact on the studied processes before to be applied in real project.

Lean construction is a management philosophy which conceptualised in three complementary dimensions: transformation, flow and value (Koskela, 1992). It is built based on Toyota production system to develop a construction workflow characterised by reduced waste, and increased value to customer through continuous improvement, in which the workflow management is improved by re-engineering construction processes based on

1 Research Fellow, School of Design and the Built Environment, Curtin Univ., Perth, Australia, +61 9266 7486, wenchi.shou@curtin.edu.au

2 Associate Professor, School of Design and the Built and Environment, Curtin Univ., Perth, Australia, +619266 4723, peng.wu@curtin.edu.au

3 Lecturer, School of Architecture and Built Environment, Deakin Univ., Melbourne, Australia, +61 5227 3544, jun.wang1@deakin.edu.au 
lean principles (Jørgensen \& Emmitt, 2008). Lean construction can be viewed as a combination of lean strategies and support lean tools to deal with variability in highly dynamic and complex systems (Thomas et al, 2002). In order to verify the benefit of changes in the complex environment, an analysis of the empirical evidence to assess the impact of the implementation of lean construction prior to real world application is needed (Shou et al, 2017). Therefore, DES is suitable for modelling complex environment and virtually simulating and assessing the efficiency and effectiveness of the lean-improved construction processes.

In response to this trend, DES was introduced into lean construction research in the 1990s and has been increasingly applied in this area because of its capability to test for the marginal contribution of each lean intervention (Agbulos et al, 2006). This method can also establish an improved construction plan to validate the results of the live experiment by overcoming its technical limitations. Sacks et al (2007) used DES to explain actual production changes in construction projects and remove the learning curve effect.

DES has been increasingly utilised as a key method to addressing issues such as the limitation of static view provided by value stream mapping (VSM) (McDonald et al, 2002), education of lean concepts (Robinson et al, 2012), and production planning and control (Bokhorst \& Slomp, 2010) in lean research. Furthermore, DES has been gradually applied as functional tools to facilitate lean construction research in specific area, such as environmental management (Golzarpoor et al, 2017), capacity management (Miclo et al, 2018) and supply chain management (Zuting et al, 2014).

Mostafa et al (2016) conducted a review of lean and agile integration within offsite construction using DES. Poshdar et al (2016) proposed a conceptual modelling as an effective solution to enhance the success of a lean construction simulation study. However, these studies focus upon specific area and therefore lack detailed discussions on the development of DES application in lean construction research.

Therefore, this study aims to understand the state of the art and propose future DES applications in lean construction research by conducting a thorough review of DES assisted lean construction research. three specific objectives are proposed as follows: (1) recognise the DES software developed during the said period, (2) identify the value created from applying DES techniques, and (3) examine the evolution of topics of DES assisted lean construction research papers during the retrieved period.

\section{RESEARCH METHOD}

There are three stages of the paper retrieving process. In Stage 1, Web of Science and Scopus are the two academic databases have been selected to identify the related papers published. Keywords, such as 'DES', 'discrete event simulation', 'simulation' and 'lean construction', were used in the 'title/abstract/keyword' fields. The papers published in the conferences of International Group of Lean Construction (IGLC) over the years were included in the review as it is the platform to showcase all these lean construction research efforts since the initiation of lean production research in the construction sector. The stage 1 search results in a total of 167 papers. 
In stage 2, a visual abstract and content review of the retrieved papers was conducted to remove less relevant or irrelevant papers from the search result in stage 1. A total of 49 articles were screened for future analysis.

In stage 3, contents analysis of the retrieved papers were conducted. The final retrieved articles were quantitatively analysed in terms of years, DES software, the value created, and lean construction research topics to determine their contributions. From Table 1, IGLC has the largest number of publications on this topic, Journal of construction engineering and management is the most utilised journal.

Table 1: number of related papers in selected journal/conference papers

\begin{tabular}{ll}
\hline Publication & No. \\
\hline IGLC & 22 \\
Journal of Construction Engineering and & \\
Management & 9 \\
Automation in construction & 4 \\
Construction Management and Economics & 3 \\
Construction Innovation & 2 \\
KSCE Journal of Civil Engineering & 2 \\
Lean Construction Journal & 2 \\
Canadian Journal of Civil Engineering & 1 \\
Journal of Cleaner Production & 1 \\
Simulation & 1 \\
Sustainability (Switzerland) & 1 \\
Revista Ingenieria de Construccion & 1 \\
\hline
\end{tabular}

\section{OVERVIEW}

\section{The Publications Distributed by Years}

Figure 1 demonstrates the publications on DES-based lean construction research started in 1997 , with the small increase in the number of publication to 2004 , followed by a soaring increase in the next 4 years, 31 papers have been published during 2005 to 2009 . However, from 2010, short decreases have been observed, ranging from 13 papers between 2010 and 2014 to the 8 papers between 2015 and 2018 .

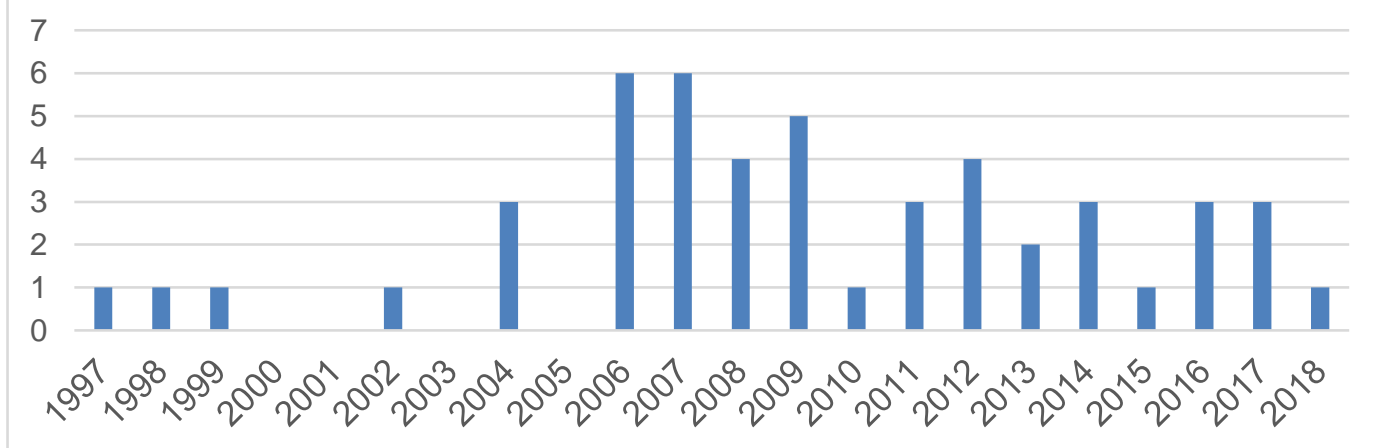


Figure 1: the publications distributed by years

\section{DISTRIBUTION OF DES SOFTWARE}

The following Table 2 shows the 13 different DES software has been used. STROBOSCOPE (State and resource-based simulation of construction processes) is the most popular simulation software used in construction sector with number of 11 references. Moreover, Simphony, Arena, CYCLONE (cyclic operations network), and ExtendSim are also popular simulation techniques in the existing articles.

Table 2: The DES software used by DES-based lean research

\begin{tabular}{ll}
\hline DES software & No. \\
\hline STROBOSCOPE & 11 \\
Simphony & 6 \\
Arena & 5 \\
CYCLONE & 5 \\
ExtendSim & 4 \\
Anylogic & 3 \\
Extend & 2 \\
Extend+BPR & 2 \\
ProModel & 2 \\
EZStrobe & 2 \\
JaamSim & 1 \\
OSim (Objektsimulator) & 1 \\
SIGMA & 1 \\
\hline
\end{tabular}

\section{THE VALUE OF DES IN LEAN CONSTRUCTION RESEARCH}

Table 3 shows the distribution of articles by the value created from applying DES techniques. 6 types of value are summarised. Simulation can be used to (1) model system to create a visual view of the process. The analysis of current performance to present the need for change, which provides a better understanding of the process dynamics to engage participants; (2) assess the effectiveness of the proposed lean systems to understand the intended benefits; (3) evaluate the alternative lean scenarios to predict and evaluate change outcomes; (4) assist with the decision to replace an existing production process with a lean system by quantifying the benefits in their specific situation; (5) measure the studied impact of lean improvement on the system by comparing pre- and post-improvement performance; and (6) validate the results of live experiment by overcoming its technical limitations.

The first observation is that many of the references coved more than one type of value. Clearly, vast of the publication is in 'alternatives evaluation to design, test and improve lean systems'. Indeed, evaluate the impact of the implementation of various recommendations is at the core of the current simulation application (Sharma et al, 2006). The 'what-is' scenarios evaluation can illustrate how production choices may affect the 
quality of delivery of a project. Followed by 'effective assessment to understand the intended benefits of the proposed improvements' with 17 references.

Table 3: The Functionalities of DES-based Lean Construction Research

\begin{tabular}{lll}
\hline No. & Functionalities & No. \\
\hline 1 & $\begin{array}{l}\text { Visualisation of the interactions between } \\
\text { systems to explain variations in the current } \\
\text { process }\end{array}$ \\
2 & $\begin{array}{l}\text { Effective assessment to understand the } \\
\text { intended benefits of the proposed }\end{array}$ \\
improvements
\end{tabular}

\section{THE TOPICS RELATED TO DES-BASED LEAN CONSTRUCTION RESEARCH}

Even though a short decrease has been observed, the publication still witnessed an overall increasing trend. Thus, summarising the topic coverage of the identified DES papers is necessary. By content analysis, this study reveals that eight topics in DES-based lean construction research are categorised, namely, (1) construction operations, (2) buffering, (3) sustainable construction, (4) production systems design, (5) agile, (6) task management, (7) design management, and (8) supply chain. All the identified papers are classified according to the main research issues solved.

\section{The Evolvement of DES-based Lean Construction Research}

Table 4 presents the number of publications of identified research topics during the studied period. It indicates that the greatest research efforts on lean construction application have been made in "construction operations" but given the least attention to "supply chain". It is notable that the research interest in "design management" and "sustainable construction" have been rising since 2009. This research can't demonstrate all the relevant studies in this area due to the limited search scope, but the research is also able to reflect the overall development of the research trend of DES-based lean construction research.

Table 4: The Distribution of Topics Related to DES-based Lean Construction Research

\begin{tabular}{llllllllllllllllllllllll}
\hline & 9 & 9 & 9 & 0 & 0 & 0 & 0 & 0 & 0 & 0 & 0 & 0 & 0 & 1 & 1 & 1 & 1 & 1 & 1 & 1 & 1 & 1 & ot \\
Topics & 7 & 8 & 9 & 0 & 1 & 2 & 3 & 4 & 5 & 6 & 7 & 8 & 9 & 0 & 1 & 2 & 3 & 4 & 5 & 6 & 7 & 8 & al \\
\hline
\end{tabular}




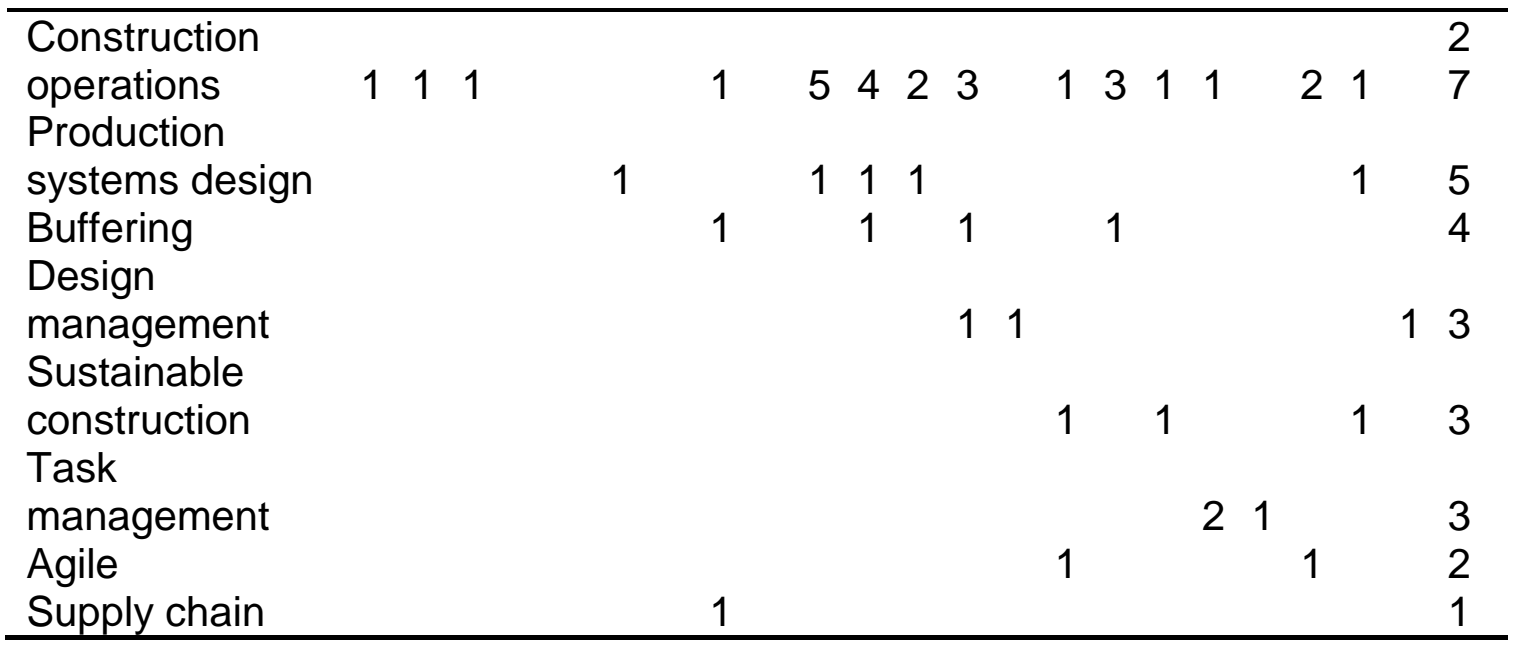

"Construction operations" began with the application of DES to describe lean construction concepts (Tommelein, 1997). The research in this topic focused on using DES to evaluate lean principles and measure their impact on the studied operation processes. Velarde et al (2009), Han et al (2012), and Ritter et al (2017) studied lean and simulation application in modular construction. From 2012, a new hotspot was Building Information Modelling (BIM) integrated construction operation simulation (Han et al, 2012; Jeong et al, 2016).

Research on "production systems design" is an important topic that DES enabled the representation of the performance metrics in the construction process, which illustrated how production system design choices may affect the project delivery. Schramm \& Formoso (2007), Schramm et al (2008), Draper \& Martinez (2002), and Draper \& Martinez (2002) demonstrated the usefulness of DES in improving decision making in production system design with the ability of evaluation of alternative designs. Li et al (2017) analysed production system based on the CONWIP method.

"Buffering", that may lead to the impact of productivity, was a research topic has been carried out in DES-based lean construction research. Alves \& Tommelein (2004) have used DES to simulate buffering and batching practice in HVAC projects. Gonzalez et al (2009) used simulation to visualise and to design work-in-process buffer for scheduling repetitive building projects. Srisuwanrat \& Ioannou (2007) investigated lead time buffer under uncertainty, Gupta et al (2012) used simulation to understand the relationship between productivity and buffers.

"Design management" is a DES-based lean construction research topic that emerged in 2009. This topic includes the study of the role of design matrix in reducing waste (Khalife et al, 2018), iteration and feedback loop in design(Hossain \& Chua, 2009), scheduling models for multiple design projects (Liu et al, 2009).

DES was proposed as a quantitative method to measure the sustainable waste during the production process. Golzarpoor et al (2017) and Golzarpoor \& González (2013) used simulation to assess production and environmental waste in the construction process. DES was regarded as an efficient method to demonstrate the benefits of changes in applying lean on sustainability (Song \& Liang, 2011). 
Hamzeh et al (2015) and Al Hattab et al (2014) used the DES to simulate task management in lookahead planning. Gurevich \& Sacks (2014) examined the effects of the proposed KanBIM production control system on task selections.

The integration of lean and agile has been a new area of research. Lu et al (2011) and Mostafa et al (2016) both utilised DES to evaluate and validate the effectiveness of the proposed lean-agile model.

The application of lean and simulation in supply chain has only been discussed in one article on time study in supply chain process (Huang et al, 2004).

\section{DISCUSSION AND CONCLUSIONS}

This paper provides a systematic review of the state of the art of DES assisted lean construction research by reviewing papers published in peer-reviewed journals and IGLC conference from 1997 to 2018. 49 DES-based lean construction research papers were identified and analysed in terms of year, value of DES, DES software, and topics. The review shows the trend of studies and DES techniques for lean construction research. The number of relevant publications indicates a growing research interest in this area.

Results of the DES software identified in this study illustrated the most popular simulation techniques which have been adopted in the construction sector. STROBOSCOPE is a programming language designed for the simulation of processes common to construction engineering (Martinez \& Ioannou, 1994), Simphony is unique to provide an environment that supports building simulation environment (AbouRizk et al, 2016), CYCLONE is a construction-oriented simulation technique (Senior \& Halpin, 1998), and EZStrobe is a general-purpose simulation program designed for modelling construction operations (Draper \& Martinez, 2002). They are the DES software designed for construction processes and have been widely applied. Anylogic is a simulation tool support DES, system dynamics, and agent-based modelling, has become a new trend of modelling tools to be applied in lean construction simulation.

The classification of DES value facilitates the application of DES. The results provide evidence that DES simulation is mainly used to investigate a wide variety of what-if scenarios about the real world system and evaluate suggested lean construction techniques to existing systems.

The eight applications of the DES-based lean construction research in the categorised topics provides evidence that DES was mainly applied in simulating lean application in general construction operations, which also indicate that lean construction contributes to planning and control in construction projects. The analysis also indicated that lean construction for sustainable construction, task management, and agile construction are the new trend of application since 2010.

Obviously, the identified 49 papers might not cover all the papers related to DES applications in lean construction research because of the retrieving rules designed. One future research direction is to conduct the review with a larger number of papers. An interesting avenue for future research is an evolutionary analysis of the simulation software applied within the topics classified, which could extent the understanding of the development of techniques as well as the interests in lean construction research. 


\section{ACKNOWLEDGMENTS}

This research was undertaken with the benefit of grants from Australian Research Council Discovery Program (Grant No. DP180104026) and Sustainable Built Environment national research centre project 2.64 .

\section{REFERENCES}

AbouRizk, S., Hague, S., Ekyalimpa, R. \& Newstead, S. (2016) Simphony: A next generation simulation modelling environment for the construction domain. Journal of Simulation, 10(3), 207-215.

Agbulos, A., Mohamed, Y., Al-Hussein, M., AbouRizk, S. \& Roesch, J. (2006) Application of lean concepts and simulation analysis to improve efficiency of drainage operations maintenance crews. Journal of Construction Engineering and Management, 132(3), 291-299.

Al Hattab, M., Zankoul, E. \& Hamzeh, F. (2014) Optimizing joint operation of two tower cranes through look-ahead planning and process simulation, Proc. 22nd Ann. Conf. of the Int'l Group for Lean Construction.

Alves, T. \& Tommelein, I. D. (2004) Simulation of buffering and batching practices in the interface detailing-fabrication-installation of HVAC ductwork. Proceedings of IGLC-12, August, Elsinore, Denmark.

Bokhorst, J. A. \& Slomp, J. (2010) Lean production control at a high-variety, low-volume parts manufacturer. Interfaces, 40(4), 303-312.

Draper, J. D. \& Martinez, J. (2002) The evaluation of alternative production system designs with discrete event simulation, Annual Conference Of The International Group For Lean Construction.

Golzarpoor, H. \& González, V. (2013) A Green-Lean simulation model for assessing environmental and production waste in construction, Proceedings of the 21th Annual Conference of the International Group for Lean Construction, Fortaleza, Brazil.

Golzarpoor, H., González, V., Shahbazpour, M. \& O’Sullivan, M. (2017) An input-output simulation model for assessing production and environmental waste in construction. Journal of cleaner production, 143, 1094-1104.

Gonzalez, V., Alarcón, L. \& Molenaar, K. (2009) Multiobjective design of Work-InProcess buffer for scheduling repetitive building projects. Automation in Construction, 18(2), 95-108.

Gupta, A., Gonzalez, V. \& Miller, G. (2012) UNDERSTANDING THE RELATIONSHIP BE-TWEEN PRODUCTIVITY AND BUFFERS IN CONSTRUCTION: A SIMULATION-BASED CASE, Proceeding IGLC-20: Twentieth Annual Conference of the International Group for Lean Construction.

Gurevich, U. \& Sacks, R. (2014) Examination of the effects of a KanBIM production control system on subcontractors' task selections in interior works. Automation in construction, 37, 81-87. 
Hamzeh, F. R., Saab, I., Tommelein, I. D. \& Ballard, G. (2015) Understanding the role of "tasks anticipated" in lookahead planning through simulation. Automation in Construction, 49, 18-26.

Han, S. H., Al-Hussein, M., Al-Jibouri, S. \& Yu, H. (2012) Automated post-simulation visualization of modular building production assembly line. Automation in construction, 21, 229-236.

Hossain, M. A. \& Chua, D. (2009) Simulation-based model for handling iteration and feedback loop in design, Proceedings of IGLC17: 17th Annual Conference of the International Group for Lean Construction.

Huang, C.-N., Seong, J. \& Russel, J. (2004) Time study on two-echelon supply chain for steel framing construction by using networking simulation model, The 12th Annual Conference on Lean Construction (IGLC), Denmark.

Jeong, W., Chang, S., Son, J. \& Yi, J.-S. (2016) BIM-integrated construction operation simulation for just-in-time production management. Sustainability, 8(11), 1106.

Jørgensen, B. \& Emmitt, S. (2008) Lost in transition: the transfer of lean manufacturing to construction. Engineering, Construction and Architectural Management, 15(4), 383-398.

Khalife, S., Mneymneh, B. E., Tawbe, A., Chatila, M. H. \& Hamzeh, F. (2018) Employing Simulation to Study the Role of Design Structure Matrix in Reducing Waste in Design, 26th Annual Conference of the International Group for Lean Construction. Chennai, India, 2018/07/18. Chennai, India.

Koskela, L. (1992) Application of the new production philosophy to construction, 72Stanford University Stanford, CA.

Li, X., Li, Z. \& Wu, G. (2017) Lean precast production system based on the CONWIP method. KSCE Journal of Civil Engineering, 1-11.

Liu, J.-J., Wang, W.-C., Cuperus, Y. \& Hirotaz, E. (2009) Simulation-based scheduling model for multiple design projects, Proceedings of the 17th Annual Conference of the International Group for Lean Construction.

Lu, W., Olofsson, T. \& Stehn, L. (2011) A lean - agile model of homebuilders' production systems. Construction Management and Economics, 29(1), 25-35.

Martinez, J. C. \& Ioannou, P. G. (1994) General purpose simulation with stroboscope, Proceedings of the 26th conference on Winter simulation. Society for Computer Simulation International.

McDonald, T., Van Aken, E. M. \& Rentes, A. F. (2002) Utilising simulation to enhance value stream mapping: a manufacturing case application. International Journal of Logistics, 5(2), 213-232.

Miclo, R., Lauras, M., Fontanili, F., Lamothe, J. \& Melnyk, S. A. (2018) Demand Driven MRP: assessment of a new approach to materials management. International Journal of Production Research, 1-16.

Mostafa, S., Chileshe, N. \& Abdelhamid, T. (2016) Lean and agile integration within offsite construction using discrete event simulation: A systematic literature review. Construction Innovation, 16(4), 483-525. 
Poshdar, M., González, V., O’Sullivan, M., Shahbazpour, M., Walker, C. \& Golzarpoor, H. (2016) The Role of Conceptual Modeling in Lean Construction Simulation, 24th Annual Conference of the International Group for Lean Construction, Boston, USA.

Ritter, C., Zhang, Y., Dupuis, R. \& Al-Hussein, M. (2017) Simulation of Production Line Improvement in Modular Home Manufacturing, 25th Annual Conference of the International Group for Lean Construction. Heraklion, Greece, 2017/07/09. Heraklion, Greece.

Robinson, S., Radnor, Z. J., Burgess, N. \& Worthington, C. (2012) SimLean: Utilising simulation in the implementation of lean in healthcare. European Journal of Operational Research, 219(1), 188-197.

Sacks, R., Esquenazi, A. \& Goldin, M. (2007) LEAPCON: Simulation of lean construction of high-rise apartment buildings. Journal of Construction Engineering and Management, 133(7), 529-539.

Schramm, F. K. \& Formoso, C. T. (2007) Using Visual Interactive Simulation to Improve Decision-Making in Production System Design. IGLC-15, Michigan, USA.

Schramm, F. K., Silveira, G. L., Paez, H., Mesa, H., Formoso, C. T. \& Echeverry, D. (2008) Using Discrete-Event Simulation to Support Decision-Makers in Production System Design and Operations, Proceedings of the 15th Annual Conference of the International Group for Lean Construction.

Senior, B. A. \& Halpin, D. W. (1998) Simplified simulation system for construction projects. Journal of Construction Engineering and Management, 124(1), 7281.

Sharma, V., Al-Hussein, M. \& AbouRizk, S. M. (2006) Residential construction lot grading approval process optimization: Case study of city of Edmonton. Journal of construction engineering and management, 132(12), 1225-1233.

Shou, W., Wang, J., Wu, P., Wang, X. \& Chong, H.-Y. (2017) A cross-sector review on the use of value stream mapping. International Journal of Production Research, 55(13), 3906-3928.

Song, L. \& Liang, D. (2011) Lean construction implementation and its implication on sustainability: a contractor's case study. Canadian Journal of Civil Engineering, 38(3), 350-359.

Srisuwanrat, C. \& Ioannou, P. G. (2007) The investigation of lead-time buffering under uncertainty using simulation and cost optimization, Proceedings of the 15th Annual Conference of the International Group for Lean Construction.

Thomas, H. R., Horman, M. J., de Souza, U. E. L. \& Zavřski, I. (2002) Reducing variability to improve performance as a lean construction principle. Journal of Construction Engineering and management, 128(2), 144-154.

Tommelein, I. D. (1997) Discrete-event simulation of lean construction processes, Proceedings of the Fifth Conference of the International Group for Lean Construction.

Velarde, G. J., Saloni, D. E., van Dyk, H. \& Giunta, M. (2009) Process flow improvement proposal using lean manufacturing philosophy and simulation techniques on a modular home manufacturer. Lean Construction Journal. 
Zuting, K., Mohapatra, P., Daultani, Y. \& Tiwari, M. (2014) A synchronized strategy to minimize vehicle dispatching time: a real example of steel industry. Advances in Manufacturing, 2(4), 333-343. 
Shou, W., Wu, P., and Wang, $J$ 